\title{
Fluorite mineralization specificities related with carbonatites in Western Transbaikalia (Arshan and Yuzhnoe ore occurrences)
}

\author{
ANNA A. REDINA ${ }^{1}$ AND ANNA G. DOROSHKEVICH ${ }^{2}$ \\ ${ }^{1}$ VS Sobolev Institute of Geology and Mineralogy SB RAS \\ ${ }^{2}$ Sobolev Institute of Geology and Mineralogy Siberian Branch \\ Russian Academy of Sciences \\ Presenting Author: redina@igm.nsc.ru
}

The Arshan and Yuzhnoe ore occurrences are located in Western Transbaikalia. There are more than 10 genetic and mineral types of the REE occurrences. The study objects are related to the stage of Mesozoic rifting (Arshan 126 $\pm 16 \mathrm{Ma}$, Yuzhnoe $122 \pm 4 \mathrm{Ma}$ ) and belong to the Late Mesozoic Central Asian Carbonatite province [1]. Carbonatites are represented by vein or pipe-like bodies. Calcite is the main rock-forming mineral. Besides fluorite, bastnaesite, sulphates, phlogopite, magnetite, and feldspar are common minerals.

The fluorite of the Arshan occurrence forms veins in early igneous minerals of carbonatites. The fluorite is found as small grains or idiomorphic crystals up to $2 \mathrm{~mm}$. The color changes both within a single crystal and from grain to grain from a dark purple to almost colorless. The fluorite of the Yuzhnoe occurrence is known in the main carbonate mass as small crystals and in earlier schlieren in the assembly with bastnaesite and albite. Early fluorite is characterized by dark purple central parts of the crystals and pale edges (crystal size of $0 . n-2 \mathrm{~mm}$ ). Fluorite crystals from the fluorite-calcite matrix are purple or lilac with the size of $0 . \mathrm{n}-3 \mathrm{~mm}$. According to the features of the REE composition, the fluorites from both occurrences have common features: REE enrichment $\left(10^{2}-10^{4} \mathrm{ppm}\right)$, predominant LREE, lack or weak Eu anomaly, slight positive $\mathrm{Y}$ anomaly. Fluid inclusion studies point out that $\mathrm{Sr}-\mathrm{Na}$ sulphates and carbonates represent the mineral phases. The gas phase composition is $\mathrm{CO}_{2} \pm \mathrm{N}_{2} \pm \mathrm{H}_{2}$. The homogenization temperatures of the primary fluid inclusions fall in the range of $400-560^{\circ} \mathrm{C}$. This study suggests that the REE-enriched fluorite precipitation occurred from high-temperature orthomagmatic sulphate-carbonate fluids, which is typical for carbonatite-related REE fluorite deposits [2].

This work was completed within the framework of the state task and supported by grant RSF 19-17-00013.

[1] Doroshkevich, Ripp (2004), Russian Geology and Geophysics 45(4), 492-50.

[2] Gagnon, Samson, Fryer \& Williams-Jones (2003), The Canadian mineralogist 41, 365-382. 